DOI https://doi.org/10.30525/978-9934-26-075-9-50

\title{
REMOTE SCREENING AND MONITORING AS A PART OF FUNCTIONAL-ORGANIZATIONAL MODEL OF THE DERMATOVENEROLOGICAL SERVICE OF UKRAINE
}

\author{
Korolenko V. V. \\ MD, MPA, Candidate of Medical Sciences, \\ Doctoral Candidate at the Department of Social Medicine and Public Health \\ Bogomolets National Medical University \\ Kyiv, Ukraine
}

The results of our analysis indicate a tendency to reduce the provision of dermatovenereological beds in Ukraine and the corresponding changes in the performance of such beds during 2009-2019. Founded correlations between the performance of such beds and the incidence of STIs and late syphilis may indicate insufficient detection of these diseases in the early stages, as well as the poor quality of treatment of identified patients in the early stages. It causes transition syphilis into the tertiary and late, including due to insufficient coordination between different levels of medical care for such patients [4]. The obtained results show the need to maintain inpatient beds for dermatovenereological patients with appropriate indications for hospitalization [13] with the simultaneous expansion of the prevention of skin diseases and STIs, starting with the early detection of general practitioners. It is necessary to take into account the presence of hospital-replacement technologies in the region. For the purpose of optimum use of available material and technical resources it is expedient to provide creation regional dermatovenereological centers based on regional dermatovenerological dispensaries $[1,6,10]$.

An important tool for hospital replacement is remote screening and monitoring based on telemedicine and mobile medicine, which are also used in Ukraine [4, c. 14]. Since May 2009, within the framework of the Euromelanoma project, a Melanoma Diagnosis Day began to be held in Ukraine. In 2009-2019, 472,374 people with nevi were examined, including 1,406 cases of melanoma and 4,210 cases of non-melanoma skin cancer [2,3].

A pilot project on remote counseling of dermatological patients was implemented based on the city clinical dermatovenereological dispensary № 1 in Donetsk and two subscriber nodes on the basis of the city dermatovenereological dispensaries of Mariupol and Kramatorsk. The work was organized according to the SAF mechanism (Store-and-forward, i.e. using the system of intermediate file storage) [5]. After the war in eastern Ukraine was begun, the integrity of this network was lost. 
Another pilot network was created in pursuance of the order of the Ministry of Health of Ukraine 2010 Mar, 23 № 261 "On the introduction of telemedicine in health care facilities" [7]. It united the Ministry of Health of Ukraine, the State Clinical Research and Practice Center for Telemedicine in Kyiv with some hospitals and scientific medical institutes. In September 2011, a multisector Memorandum of understanding on the introduction of telemedicine technologies was signed. By the end of 2012, it was planned to create the national network of regional hospitals throughout Ukraine [8], however, it was not implemented.

After the adoption in 2017 of the Law "On improving the availability and quality of health care in rural areas" [9] preparations for the signing of a Memorandum of Cooperation between the Ministry of Regional Development, the Ministry of Health, the World Bank and the Ministry of Foreign Affairs of Canada on the introduction of telemedicine in Ukraine have begun. This Memorandum was signed at the end of 2018, then the introduction of telemedicine in a pilot mode began in Kirovohrad, Kharkiv, Rivne, Dnipropetrovsk and Poltava regions. The pilot project was launched in four areas: cardiovascular disease, diabetes, bronchial asthma and dermatological diseases. During 2018, 3287 telemedicine consultations were provided [12].

In addition, there are professional telemedicine services in Ukraine ("Medinet", "Polyclinic without queues", "Telemed24", "Doctor Online", "Medikit"), of which the most common is the platform "Medinet". Its network unites 431 health care institutions and more than 4500 physicians in Odessa, Kharkiv, Zhytomyr, Zaporizhia, Kherson, Vinnytsia regions [12]. During 2019, about 10,000 teleconsultations were provided within this network in four main areas: cardiology, pulmonology, dermatology and endocrinology. [11].

Conclusions. A significant reduction of the dermatovenereological service resources, including facilities, provision and operation of the beds has led to an intensification of their use and to decrease in the availability of medical care. The tendency to increase the late, complicated forms of STIs, the formation of the corresponding negative consequences for the health of the population necessitate the improvement of the dermatovenereological service with the preservation of rational resources of inpatient dermatovenereological care.

To optimize logistics, it is advisable to concentrate relevant resources by creating regional dermatovenereological centers based on regional dermatovenereological dispensaries, as well as to provide structural units of remote screening and monitoring (telemedicine and mobile medicine) within these centers and the Institute of Dermatology and Venereology of National Academy of Medical Sciences of Uktaine. It will streamline the use of available logistical, technological, information abilities and proper use of human resources. 


\section{References:}

1. Волкославська В.М. Стан та основні організаційні задачі дерматовенерологічної служби на сучасному етапі в Україні. Дерматологія та венерологія. 2015. №2. С. 85-93.

2. День діагностики меланоми в Україні. СТОП-МЕЛАНОМА, 2021. URL: https://stop-melanoma.net/

3. День діагностики меланоми. Офіційна інформація УАЛДВК. Укр. журн. дерматол., венерол., косметол. 2012. № 2 (45). С. 12-14.

4. Короленко В.В., Грузєва Т.С. Особливості стаціонарного лікування пацієнтів із хворобами шкіри та інфекціями, що передаються статевим шляхом. Патологія. 2020. №3. С. 402-407. doi: 10.14739/23101237.2020.3.221873

5. Куценко И.В. Использование информационных технологий для оказания дерматологической помощи жителям Донецкой области. Укр. журн. телемедицини та медичної телематики. 2004. № 2 (1). С. 80-84.

6. Парій В.Д., Грищук С.М., Борис В.М. Визначення показників для проведення оптимізації ліжкового фонду закладів охорони здоров'я госпітального округу. ScienceRise. Medical science. 2015. № 10(3). C. 97-100. .

7. Про впровадження телемедицини в закладах охорони здоров'я. Наказ Міністерства охорони здоров'я України від 23.03.2010 № 261. URL: https://zakon.rada.gov.ua/rada/show/v0261282-10\#Text

8. Про затвердження плану заходів щодо реалізації положень Меморандуму про взаєморозуміння між МОЗ України, НАМНУ, ТОВ "ДТЕК", Благодійним фондом "Розвиток України" та ПАТ "МТС Україна". Наказ Міністерства охорони здоров’я України від 26.12.2011 № 966. URL: https://zakon.rada.gov.ua/rada/show/v0966282-11\#Text

9. Про підвищення доступності та якості медичного обслуговування у сільській місцевості. Закон України від 14 листопада 2017 року № 2206-VIII. URL: https://zakon.rada.gov.ua/laws/show/2206-19\#Text

10. Степаненко В.І., Коляденко В.Г., Рижко П.П., Хара О.І. Стан та проблеми дерматовенерологічної служби в Україні. Реалії сьогодення, перспективи майбутнього. Укр. журн. дерматол., венерол., косметол. 2004. №3. С. 4-8.

11. Телемедицина в практиці лікаря та середнього медперсоналу. Medinet, телемедична мережа України. 2021. URL: https://medinet.com.ua/ telemedytsyna-v-praktytsi-likarya

12. Телемедичні сервіси та мобільні рішення в Україні та світі. Medinet, телемедична мережа України. 2021. URL: https://medinet.com.ua/ telemedychni-servisy\#rec215956804 
13. Finlay A.Y., Anstey A.V. Dermatology inpatient care in the U.K.: rarely possible, hard to defend but occasionally essential. British Journal of Dermatology. 2019. №180(3). P.440-442. doi: 10.1111/bjd.17501.

14. Lee J.J., English J.C. 3rd. Teledermatology: A Review and Update. Am J Clin Dermatol. 2018. №19(2). P.253-260. doi: 10.1007/s40257017-0317-6.

DOI https://doi.org/10.30525/978-9934-26-075-9-51

\section{МЕДИКО-СОЦАЛЬНІ ЧИННИКИ ТА ФІЗИЧНИЙ РОЗВИТОК ДІТЕЙ ШКІЛЬНОГО ВІКУ}

\section{Пересипкіна Т. В.}

кандидат медичних наук, старший науковий співробітник, завідувач наукової організачї медичної допомоги школярам і підліткам ДУ «Інститут охорони здоров'я дітей та підлітків Національної академії медичних наук України»

\section{Сидоренко Т. П.}

кандидат медичних наук, старший науковий співробітник дочент кафедри гігієни та соиіальної медицини

Харківський національний університет імені В. Н. Каразіна

\section{Голубнича Г. I.}

асистент кафедри гігієни та соиіальної медиџини

Харківський начіональний університет імені В. Н. Каразіна

Зінчук А. М.

кандидат медичних наук,

старший науковий співробітник відділення наукової організаиії

медичної допомоги школярам і підліткам

ДУ «Інститут охорони здоров'я дітей та підлітків Національної

академї медичних наук України»

\section{Пересипкіна А. М.}

асистент кафедри педіатріі

Харківський наиіональний університет імені В. Н. Каразіна м. Харків, Україна

Фізичний розвиток є одним з важливих критеріїв для характеристики санітарно-епідеміологічного благополуччя населення, показником рівня 